\title{
The Influence of Food and Beverages in Human Life According to Buya Hamka (Analysis Study of Tafsir Al-Azhar)
}

\author{
Rifqy Jauhar Fuady*1, Akmaliyah ${ }^{1}$ \\ ${ }^{1}$ UIN Sunan Gunung Djati Bandung \\ A.H. Nasution street no. 105, Cibiru, Bandung, West Java, 40614, Indonesia \\ e-mail: *1 rifqyjfuady1001@gmail.com
}

*Correspondent Author

DOI: $10.5575 /$ ijhar.v2i1.7704

\begin{abstract}
Al-Quran is a book of life, containing various rules concerning the order of human life in the world and the results of that life in the hereafter. Therefore it is certain that the Quran talks about food. The term food in Arabic is mentioned with 3 pieces of the terms. These are: "aklun, tha'am, and ghiza 'un. But of these three terms, the Quran uses only two, namely tha'am, and aklun.This study aimed to determine the influence of food in human life by taking a few verses in Quran according to Buya Hamka's point of view in Tafsir al-azhar. Based on the results of the discussion, Buya Hamka in interpreting food verses in Tafsir al-Azhar's cannot be separated from the correlation between verses one with the other verses, so that a complete understanding of the concept of food can be obtained. Based on the verses studied, it can be understood that the meaning of food in the interpretation of Buya Hamka, is grouped into various terms, namely, healthy food, eating food proportionally according to needs, having a sense of security towards food, food as a cry, food as a warning, and food as gift.The influence of food on human life has a profound effect on a person's soul, including praying, making the soul so calm, whereas a bribe is forbidden in one's stomach, then his worship will not be accepted for forty days, bad food will damage health and soul.
\end{abstract}

Keywords: aklun, ghidha' un, Hamka, human, tha'am.

\section{Introduction}

Like a diamond, the Quran with all its angles is able to emit light that is different from one angle to other angles, and it is not impossible if we invite others to look at it, then they will see more than what we see". This illustration has described that the Quran as a text has enabled many people to see different meanings in it. With a variety of methodologies that are presented, the commentators often seem to have their own style which is very interesting to explore. Starting from interpreting the word in each verse to connecting it with the problems of fiqh, politics, economics, sufism, literature, kalam, and others.

Religion needs interpretation of God's message in their holy books to make it easier for people to understand the meaning it. That interpretation is also what ultimately has to open up conceptual and historical studies through the comprehension of interpretations (Chamami, 2012).
Al-Quran is a source of tasyri' and law, which Muslims have to know, explore and practice all its contents. Al-Quran contains the explanation of halal-haram, commands and prohibitions, ethics and morals, and others, which will guide people who claim the Quran as the Holy Book. It is necessary because holding on the teachings of the Quran is a source of happiness, guidance and victory in God's side in the form of paradise full of pleasure. The diversity of meanings of the recital contained in the Quran has its own value in terms of understanding the verses. There are many recital found in the Quran that have different meanings, and for different purposes. So it is not surprising that there are many interpretations appear from one term in the Quran. This is proof of the vastness of knowledge contained in the Quran.

Among the greatest ethics in reading the Quran inwardly is getting the meanings of the Quran. Tafakkur is directing the heart or mind to pay attention to the proposition, while 
Tadabbur is directing it to pay attention to the consequences of something and what happens next (Al-Qardawi, 1999). This is reflected in the word of Allah Almighty on QS. 38, Sad: 29.

"This is a book that We send down to you full of blessings so that they pay attention to the verses and to learn from those who have thoughts".

The verse above contains instructions to pay attention or to do Tadabbur to the verses of the Quran, with the aims that the observers can get lessons and knowledge from these verses. Quraish Shihab, regarding the meanings contained in the Quran, stated: "there are no readings like the Quran, we can learn not only the editorial composition and selection of vocabulary but also the contents that are written, implied even to the impression it makes" (Shihab, 2005).

In the Quran, there are few verses that talk about a variety of things, including food which is still relevant and interesting to study. The human beings in their capacity as living creatures cannot be separated from various kinds of needs to be able to carry on their lives. The need theory assumes that actions taken by humans are essentially to meet their needs, both physical and psychological needs.

Some of Maslow's important theories are based on the assumption that there is a positive urge in humans to grow and fight forces that oppose and hinder growth. The satisfaction of each level of specific needs can be done if the previous level of needs is met, and then Maslow divides it into five levels as follows:

1. Physiological needs. This need is a basic need that is primary and vital, which involves the basic biological functions of human organisms such as the need for food, clothing and shelter, physical health and so on.

2. Safety needs, such as a guarantee of security, protected from the dangers and threats of disease, the war, poverty, hunger, and unfair treatment.

3. Social needs, including the need for love, the need of recognition as a person in a group, loyal friends, and cooperation.

4. Esteem needs, including the needs to be valued because of achievement, ability, position or status, rank and so on.

5. Self-actualization needs, such as the need to enhance the potential possessed, maximum self-development, creativity, and self-expression (Purwanto, 2010)

Based on the descriptions above illustrate that food is categorized as the physiological needs in the first level to be fulfilled.

One of the Tafsir books published in Indonesia is the Tafsir al-Azhar by Hamka. This Tafsir is known as one of the interpretations which provide interesting scientific treasures in terms of language, as well as the presentation of the reasoning behind it. In this context, Buya Hamka is one of the scientists of Islam and a commentator who has a high concern for social issues, including food. His track record in the realm of Indonesian interpretation has been proven by his monumental work, namely the Tafsir of al-Azhar. Therefore, examining and revealing Buya Hamka's views on food issues in this interpretation is an interesting fact to be examined.

The choice of Tafsir al-Azhar by Abdul Malik Karim Amrullah (Hamka) is interesting not only because of the product of Indonesian scholar, but also Hamka has broad knowledge that known by a wide audience. By borrowing the expression Abdurrahman Wahid or commonly called "Gusdur", "Hamka is able to demonstrate the extent of his knowledge in almost all disciplines of Islam as well as his knowledge of non-religious affair" (Wahid et al., 1984).

While the character was chosen because he was considered capable of making interesting contributions regarding the meaning of verses related to foodsand his interpretation style which was strongly influenced by his knowledge in the field of language including nahwu, theology, logic, fiqh, and history. While interpreting the verses of the Quran, he does not have a specific tendency to use specific patterns, such as fiqh, aqidah or something else. Besides that, Buya Hamka is also one of the commentators who tries to combine the narration (ma'tsur) and reason (ra'yu) to strengthen his argument. It considered can facilitate the understanding of the clues to scriptures (Jalal et al., 1990).

Food themes in the Quran have things that ought to be revealed such as the various types of food that are mentioned in the Quran. Based on this reason the author wants to describe and analyze how the actual description of food in the Quran by taking a few verses according to Buya Hamka's point of view. 


\section{Methods}

The method used in this research was the thematic tafsir method (maudu'i). It is a method of interpretation that discusses the verses of the Quran in accordance with the theme or title that has been determined. (In line with what was stated by Saladin Hamid, that the tafsir maudu'i is a method of interpretation using the choice of specific topics in the Quran (Hamid, 2006).

This study used a qualitative approach based on the formulation of a research problem that requires researchers to understand and explain the problem through intensive communication with data sources. Qualitative research is research that emphasizes the quality or the most important thing of an item or service in the form of events/social phenomena behind these events that can be used as valuable lessons for a development of theoretical concepts (Sugiyono, 2017).

The descriptive method was used in this research to describe the actual facts in the field and the nature of a particular population systematically. Winarno Surakhmad stated that this descriptive investigation was aimed to solve the existing problems (Surakhmad, 2004).

Logical and accurate qualitative data were collected. The data were taken in the form of primary data that directly related to the topic of discussion in this study, such as interviews about the vision, mission, programs, implementation, and evaluation of educational philosophy in the school curriculum. While secondary data were obtained from books or documents that support research.

\section{Results and Discussion}

\subsection{History of Buya Hamka}

Prof. Dr. Haji Abdul Malik Karim Amrullah or better known as Hamka which is the acronym of his full name is an Indonesian intellectual who has down-to-earth thinking and future vision, this statement is not an exaggeration if we see how many of Hamka's works and ideas have contributed to the world, especially Islam (Written as Hamka henceforth). He was born on February 17, 1908 or 14 Muharram 1326 Hijriyah in the village of Molek, Maninjau, West Sumatra, Indonesia. The word "hajj" was originally obtained after performing the pilgrimage in 1927 in the holy city of Mecca (Hasan, 2004).

His father, Sheikh Abdul Karim bin Amrullah was founder of Sumatra Tawalib in Padang Panjang (Shadily, 2008), has great desire that his children will follow the same footsteps as he has taken as an ulema. Hamka recounts that in his autobiography when he was born, his father Sheikh Abdul Karim bin Amrullah muttered, "Ten years". When he was asked what that meant, he replied: "he will be sent to study in Mecca for ten years, so that he will become pious like me, like his grandmother and like his old grandmothers".

Hamka besides known as an Indonesian writer, Hamka was also well known asa cleric, philosopher, and political activist. He was declared as a National Hero of Indonesia after the issuance of Presidential Decree No. 113/TK/ 2011 on November 9, 2011 (Muhammad, 2006). Hamka is one of the Indonesian writer who wrote and published books the most. Therefore he was dubbed as Hamzah Fansuri in the modern era. Later he was given the title Buya, a nickname for the Minangkabau people which came from the word abi or abuya in Arabic which mean my father or someone who was respected. Hamka came from the cape tribe in Minangkabau, same as the tribe of his mother Siti Safiyah Tanjung. Hamka was also a well-known influential preacher in Southeast Asia. His father was a pioneer figure in the "Kaum Muda" movement in Minangkabau. Hamka's grandfather was Shaykh Amrullah, he was a murshid from the Naqsabandiyah order, according to the story of Shaykh Amrullah (Hamka's grandfather) had been married 8 times, and from that marriage he had 46 children.

Hamka was born in the early days of the "Kaum Muda" movement, spearheaded by four Minang scholars, Haji Abdul Karim Amrullah or commonly known as Hajj Rasul (Hamka's father), Shaykh Taher Jalaluddin, Shaykh Muhammad Jamil Jambek and Haji Abdullah Ahmad.

Hamka's intellectual journey began by learning reading the Koran in his hometown with his parents, at the same time he entered the village school for 3 years (morning) and the Diniyyah Religious school (evening) which was founded by Zainuddin Labai al-Yunusi in Padang Panjang and Parabek (Bukit Tinggi) for 3 years. In the evening Hamka with her friends went to the mosque to read the Quran (Hamka, 1985). That was the Hamka's daily activities in his childhood. That daily routine of activities has blinded him and he felt "constrained" by the attitude of his authoritarian father. Such conditions make Hamka's behavior distorted, to 
the point that he is known as a "naughty child". This condition was justified by AR Sultan Mansur, a man who greatly influenced Hamka's personal growth as a Preacher. Since he was a child, even though he was known as a bad boy, Hamka was an intelligent person, he was talented in the field of language, not surprisingly since he was able to read a variety of literature in Arabic, including various translations of Western writings. Since he was young Hamka was known as a traveler, so his father gave him the title "The Bachelors Away".

Before entering school, Hamka lived with her grandmother in a house near Danau Maninjau. When he was six years old, he moved with his father to Padang Panjang. Like most boys in Minangkabau, when he was a child, he studied the Quran and slept in the surau near his house because Minang boys usually did not have a place at home. In surau, he learns the Quran and silek, while outside of it, he likes to listen to kaba, the stories sung with traditional Minangkabau musical instruments (Tamara, 1997).

In 1924, he planned to go to Java at the age of 16, but unfortunately, Hamka's departure to Java postponed as he was struck by a smallpox outbreak in the Bengkulen area. These conditions made Hamka must lie in a bed for two months, after recovering he did not continue his journey instead he returned to Padang Panjang with a face full of smallpox scars. Hamka's failure to go to Java did not diminish his intention, a year later Hamka went to Central Java.

Hamka's intellectual journey in Java started when he was in Yogyakarta, the city where the organization of Muhamadiyah was born. Through his uncle Ja'far Amrullah, Hamka began to study organization and attended courses organized by Muhamadiyah and the Syarikat Islam. There he learned about the world of the modern Islamic movement through H. Oemar Said Jokroaminoto whose from him Hamka had heard lectures on Islam and socialism, and from Ki Bagus Hadikusumo (chairman of Muhamadiyyah 1944-1952), he received knowledge about the interpretation of the Quran. Yogyakarta is a city that has important meaning for the development of Hamka's scientific and religious awareness, so he mentioned that in Yogyakarta he found Islam as a living thing, which offered a dynamic stance and struggle (Shabahussurur, 2008).
After traveling in Java in July 1925 at the age of 17, he returned to Padang Panjang. He implements the knowledge obtained from the land of Java through speech and lectures, thanks to his skill in arranging the words so that he was admired by his peers. Sometimes he wrote speech texts for his friends and was published in a magazine he leads, called Khatibul Ummah.

In February 1927 he went to Mecca to perform the pilgrimage and lived there for 6 months, during his stay in Mecca he worked at a printing company and in July he returned to Indonesia. Before returning to his hometown, he stayed in Medan and had become a religious teacher on a plantation for several months.

In 1949 he moved to Jakarta and began his career by working as a class $\mathrm{F}$ civil servant in the Ministry of Religion which was led by KH. Abdul Wahab Hasyim. Besides working as a civil servant, he also taught at Islamic institutions including IAIN Yogyakarta, Jakarta Islamic University, Muhamadiyah Faculty of Law and Philosophy in Padang Panjang, Indonesian Muslim University (MUI) in Makasar, Islamic University of North Sumatra. In 1950 he visited various countries in the Middle East. In 1952 he also had the opportunity to visit the United States at the invitation of the Ministry of Foreign Affairs of the United State. In 1958 he was sent to attend an Islamic symposium in Lahore and then he delivered a promotion speech to obtain the title Doctor Honoris Causa at al-Azhar University, Egypt, with the title of the speech "The Influence of Muhammad Abduh in Indonesia". In addition, he also earned the Doctor Honoris Causa degree at the Malaysian National University in 1974. On that occasion, the Malaysian Prime Minister said "Hamka did not only belong to the Indonesian people but also the pride of Southeast Asian nations" (Ensiklopedi Islam, 2003).

During the Old Order era, he had been in custody for several years. During this time, he completed the tafsir of al-Azhar. Hamka wrote hundreds of titles books about Islam. He was the imam of the Al-Azhar Kebayoran mosque. He once led the Majalah panji rakyat that has published since 1959 .

After resigning from the post of chairman of MUI, his health declined. On the advice of doctor Karnen Bratawijaya, he was hospitalized at Pertamina Central Hospital on July 18, 1981, which coincided with the beginning of 
Ramadan. Hamka died on Friday, July 24, 1981 , at 10:37 at the age of 73 years.

\subsection{Food Category}

Food defined as everything that can be eaten (such as snacks, side dishes, cakes) or any material that we eat or enter the body that forms or replaces body tissues, energizes, or regulates all processes in the body. Regarding the discussion about food, one of the verses in the Quran 80, 'Abasa: 24, reads:

\section{"Then let the mankind pay attention to his food"}

Although this verse is general in nature, it can be understood specifically that there are suggestions for paying attention and carefully choosing the type of food to be consumed. The types of food and the rules in the process of consuming something, especially for the believers, are regulated and contained in the Quran.

Dozens of verses in the Quran have the words referred to food, even though they are similar meanings, a slight difference meaning found from one another.It is interesting to note that the language of the Quran uses the word akala in various forms to refer to the activity of "eating" But it also means all activities and businesses (Shihab, 2005). The term food in Arabic can be referred to 3 words namely aklun, tha'am and ghidha'un. Among these three terms, the Quran uses only two, namely tha'am and aklun. The word tha'am and various forms of derivation are mentioned 48 times in the Quran, which mostly talks about various aspects related to food. While the word aklun, and various forms of derivation are mentioned 109 times in the Quran.

To understand the meaning of the concept of food in the Quran is by collectingall the texts and analyze them. Regarding this problem, Ibn Taimiyyah said:

"If a lafaz is mentioned in the Quran or al-Hadith, then other similar lafazs must also be mentioned, what exactly does God and His Prophet want with these lafazs. In this way we can know the language of the Quran and alHadith".

However, before going any further following the author aklun terms of etymological and terminological.

Etymologically, the al-Munjid dictionary ذاق الثئ as defines the term tha'am (طعام). as (tasting something). In addition, according to other sources, it is said that the meaning of lafaz tha'am is كل ما يؤكل أو ذاق مثال (everything that is eaten or tastedan example) (Taimiyyah, 1999).

Whereas terminologically, Quraish Shihab argues that food or tha'am in the language of the Quran is anything that is eaten or tasted. Therefore, "drinks" are also included in the meaning of tha'am. Al-Quran surah AlBaqarah verse 249 uses the words syariba (drinking) and yat 'am (eating) for objects related to drinking water (al-Bāqī, 2010).

Based on the description of the data above, it can be concluded that the term "tha'am" is mostly in the form of ism (noun) form. So it is more indicating to the nature of food itself in the literal sense.

Etymologically, The term aklun (أكل) derived from the formation of lafaz akala (أكل) which means taking food then swallowing it after chewing it. While al-Asfahani means taking food and all means or efforts that resemble the act. But some are only interpreting the lafaz akala (أكل) with مضغالطعامويلعه (chewing food then swallows it). Whereas 'Abdullah' Abbas al-Nadwi categorizes aklun (أكل) as a form of a noun which means food.

One form of the derivation oflafaz aklun (أكل) is lafaz aklan (أكلا) which is categorized as a form of accusative (patient object) which contains the meaning of the act or state of eating (actions or state of food). Another form that also has quite significant differences in meaning is lafaz ukulun (أكل) means الثم (fruit). This is a different meaning iletters 5 marked with sukun (ं) become uklun (أكل). So the meaning also becomes rizki or rizki that is broad. While terminologically, the term food according to Quraish Shihab, the Quran uses the word akala in various forms to indicate the activity of "eating". But the word does not merely mean "inserting something throat", but also shows the meaning of all activities and endeavors. This is for example reflected in QS. 4, al-Nisa': 4:

"Give the dowry to the woman (whom you marry) as a gift of full will. Then if they hand over to you some of the dowry with pleasure, then eat (take) the gift (as food) which is as good as a result".

As commonly known that the dowry do not have to be food. But in this verse uses the word "eat" used for the dowry. The Word of Allah Almighty in QS. 6, al-Anam: 121: 
"And do not eat animals that are not called the name of Allah when slaughtering them. Indeed, such an act is ungodliness. Indeed, the devil whispers to his friends so that they refute you, and if you obey them, surely you will be polytheists".

Shaykh 'Abd al-Halim Mahmud former supreme leader of al-Azhar understands the word "eat" in this verse as a prohibition to perform activities of any sort is not accompanied by the name of God. It is understood that the meaning of the word "eating" here in a broad sense is "all forms of activity". The use of the word seems to state that activity requires calories, and calories are obtained through food.

Based on the description of the data above, it can be concluded that the majority of the pronunciation contained in the Quran is in the form of fi'il (verb). This shows that the pronunciation in the Quran indicates a process of consumption. However, this attitude is not merely interpreted in the form of activities related to mere consumption processes, even more so in the form of activities in general. This can be seen from the classification chart of the second lafaz aklun which is arranged based on the themes contained in the Koran. Because based on the information obtained from the chart proves that lafaz aklun is also used for the process of consuming non-food objects that are not commonly consumed by humans (literally), such as property, fortune, and so forth. So in general lafaz aklun here can be interpreted as taking or obtaining (تناول).

\subsection{The Effect of Food on Human Life according to Buya Hamka in Tafsir al- Azhar.}

It is undeniable that food has a huge influence on human physical growth and health. The issue to be addressed here is its effect on the human soul. Al-Harali a great scholar (d.1232 AD) argues that the type of food and drink can affect the soul and mental characteristics of its eaters. This scholar concluded his opinion by analyzing the word rijs mentioned by the Koran as a reason to forbid certain foods, such as the prohibition of liquor (QS. 6, Al-Anam: 145).The word "rijs", according to him means "bad character and moral depravity", so that if God calls certain types of food and evaluates them as rijs, then this means that these foods can cause bad
character.Indeed this word is also used by the Quran for bad deeds that describe mental depravity, such as gambling and idolatry (QS. 5, Al-Māidah: 90) thus, the opinion of AlHarali above is quite reasonable in terms of the language used the Quran.

This opinion is In line with the opinion expressed by a contemporary scholar, Shaykh Taqi Falsafi in his book, Child between Heredity and Education. In this book, he corroborates his opinion by quoting Alexis Carrel writing in Man the Unknown as follows:

The effect of a mixture of chemical compounds contained in food on the activities of the human soul and mind has not been fully known, because sufficient experiments have not been carried out. However, it cannot only affect the human body but also the soul and feelings. Several studies have shown that liquor is the initial steps that result in the following steps from the criminals. This is due, among others by the influence of the drink in the soul and his mind. (Shihab, 2007).

So based on the interpretation of Buya Hamka in Tafsir al-Azhar, the verse that is related to the influence of food on human life is chosen as follows:

1. In QS. 2, al-Baqarah: 168; If humans have arranged to eat and drink, seek from a halal source, not from fraud, not from what in modern times is called corruption, then the soul will be preserved from the rudeness. Based on the hadith discussed in Buya Hamka's explanation that if a man eats halal food, surely God will accept his prayers. And who throws an unclean bite into his stomach, then his deeds will not be received for forty days. And whoever among the servants of Allah grows his flesh from illicit wealth and usury, then fire is better for him.

2. In QS. 2, al-Baqarah: 172; Food is very influential on the soul and attitude of life. Food also determines the subtleties or rudeness of one's mind. The reason for believers that eating is not merely a matter of filled belly but also to strengthen the body that leads to a strong and healthy body, open mind, and gratitude to God deepens. Of course there are also those that are prohibited, which is not good food. Because bad food will damage not only health and but also damage the mind. If someone wants to pray in the sight of God, he should take care of his food, not to eat 
unclean food. Stomach is full of illicit food, will affect the soul and cause always encounter bad dreams.

3. In QS. 2, al-Baqarah: 275; Person who lives from usury, his life is always difficult even though his money has millions of interest.

4. In QS. 7, al-A'raf: 31: Because excessive eating can also cause disease. God does not like people who extravagant more than what he earns. Wasteful means bringing harm to themselves.

5. In QS. 16, An-Nahl: 114; Halal and good food, has a profound effect on the soul; make the soul calm.

6. In QS. 23, al-Mu'minun: 51; How close the relationship between food hygiene and mental hygiene. A soul that is upright who able to control others is a soul that is able to control itself. A leader's words will not be heard if he eats foods from illicit wealth.. If food taken into our stomachs is taken from good property that is lawful, it also affects the blood path in the body (physically) and affects the way the brain thinks (spiritually). If our livelihoods are halal, we will not feelin debted inwardly, and we are able to open our mouths to reprimand others' mistakes. And the heart is also strong in doing righteous deeds. It is mentioned in several prophetic traditions that a worship will not be immediately accepted by God, if in the stomach there is still unclean food.

\section{Conclusion}

According to Buya Hamka Interpretation related to the influence of food on human life, it can conclude in the following statement: Halal and good food has a profound effect on the soul, make the soul calm, and God will accept the ones' prayers who eat halal foods. Foods from a bribe are unclean in his stomach, then his deeds will not be received for forty days, his worship will not be accepted by God, bad food will damage health and also damage the mind. Food is very influential in the soul and attitude of life. Food also determines the subtleties or roughness of one's mind. If food enters our stomachs taken from a good property that is lawful, he also affects the blood path in the body, and influence the way the brain thinks.

\section{Acknowledgement}

The author sincerely thanks supervisor Mr. Opik Taufik Kurahman and all colleagues from UIN Sunan Gunung Djati who providing support, insight and expertise that greatly assisted the research.

\section{References}

Al-Qardhāwi, Y. (1999). Berinteraksi dengan al-Quran. terj. oleh Abdul Hayyie alKattani, Jakarta: Gema Insani Prees.

Baidan, N. (2000). Metodologi Penafsiran alQur'an. Yogyakarta: Pustaka Pelajar,

Chamami, Rikza. (2002). Studi Islam Kontemporer. Semarang: Pustaka Rizki Putra.

Ensiklopedi Islam. (1993). Jakarta: PT. Ikhtiar Baru Van Hoeve.

Hamid, S. (2006). Studi Ulumul Quran. Jakarta: Intimedia Ciptanusantara,

HAMKA. (1991). Lembaga Hidup, Jakarta: Pustaka Panjimas.

(1985) Tafsir al-Azhar. Jakarta: Pustaka Panjimas.

Hasan, A. (2004). Tokoh-Tokoh Masyhur Dunia Islam. Surabaya: Jawara Surabaya.

Jalal \& H. A. Abdul. (1990). Urgensi Tafsir Maudu'i pada Masa Kini. Jakarta: Kalam Mulia.

Ma'luf, L. (1997) Qamus al-Munjid fì alLughah. Beirut: Dar al-Masyriq.

Muhammad, H et al. (2006) Tokoh-tokoh Islam yang Berpengaruh Abad 20. Jakarta: Gema Insani.

Panitia Peringatan Buku 70 Tahun Buya Prof. Dr. Hamka. (1983). Kenang-kenangan 70 Tahun Buya Hamka. Jakarta: Pustaka Panjimas.

Pius A. Partanto \& M. Dahlan al-Barry. (2004). Kamus Ilmiah Populer. Surabaya: Penerbit Arkola.

Purwanto, N. (2000) Psikologi Pendidikan. Bandung: Remaja Rosdakarya.

Shabahussurur. (2008). Mengenang 100 tahun Haji Abdul Malik Karim Amrullah Hamka. Jakarta: Yayasan Pesantren Islam Al-Azhar.

Shadily, H. (2008). Ensiklopedi Umum. Yogyakarta: Kanisius.

Shihab, M. Q. (2005) Wawasan al-Quran. Bandung: Mizan.

(2005). Wawasan Alquran: Tafsir Maudu'i Atas Berbagai Persoalan Umat. Bandung: Mizan. 
Sugiyono. (2017). Statistika Untuk Penelitian. Bandung: Alfabeta, 2017.

Surakhmad, W. (2004). Pengantar Penelitian Ilmiah Dasar Metoda Teknik. Bandung: Tarsito.

Taimiyyah, Ibn.Al-Fatawa. (1999). Beirut: Dar al-Fikr. t. t., juz VII
Tamara, N. (1996). Hamka di Mata Hati Umat. Jakarta: Sinar Harapan.

Yusuf, Y. (2003). Corak Pemikiran Kalam Tafsir Al-Azhar. Jakarta: Pustaka Panjimas. 